\title{
Determination of the causes of the non-linking of SMEs with public entities
}

\author{
Determinación de las causas de la no vinculación de las PyMES con las entidades \\ públicas
}

\author{
SALAZAR-PAVÓN, Eliazar, ESPARZA-TOVAR, Citlalli, GUILLEN-RAMÍREZ, Mirna Liliana and \\ BECERRA-BUSTAMANTE, Diana Michel
}

Universadad Tecnológica Paso del Norte

ID $1^{\text {st }}$ Author: Eliazar, Salazar-Pavón / ORC ID: 0000000331277080

ID 1 $1^{\text {st }}$ Coauthor: Citlalli, Esparza-Tovar / ORC ID: 0000000278364213

ID $2^{\text {nd }}$ Coauthor: Mirna Liliana, Guillen-Ramírez / ORC ID: 0000000318540921

ID $3^{\text {rd }}$ Coauthor: Diana Michel, Becerra-Bustamante / ORC ID: 0000000182727534

DOI: $10.35429 /$ JPE.2019.5.3.38.44

Received September 20, 2019; Accepted November 13, 2019

\begin{abstract}
SMEs, are a core point in our country, and are the innovative and creative part that few companies can achieve this result, in Ciudad Juarez specifically and according to the present research we find small and medium companies such as designers of robots, designers of dresses, bakeries, designers of pipelines, distributors of snacks, food, furniture designers, designs of parts of machinery, companies with great added value of which its existence is unknown. According to statistics from the Business Directory of the National Institute of Geography and Information Technology (INEGI), more than $85.7 \%$ of SMEs do not have the knowledge of the support offered by the government, and $14.3 \%$ of companies have knowledge of promotion programs and state government support the highest percentage knows the Entrepreneur Support Network, reaching $61.1 \%$, followed by the Let's Grow Together program with $42.6 \%$, as well as other INADEM programs with 39.4 percent. This creates a problem since these types of companies require the support of the public sector and in the same way the public sector needs to prove the destiny of these designated supports. Then we ask ourselves the research question: if there are innovative SMEs and there are resources in the public sector, then what are the causes of non-linking? This theme is the central point of the present investigation.
\end{abstract}

SMEs, INEGI, Manufacturing industry, Companies, Public sector, Entrepreneurs

\begin{abstract}
Resumen
Las PYMES, son un punto medular en nuestro país, y son la parte innovadora y de creación de ideas que pocas empresas pueden conseguir este resultado, en ciudad Juárez en específico y de acuerdo con la presente investigación encontramos pequeñas y medianas empresas como, diseñadoras de robots, diseñadores de vestidos, panaderías, diseñadores de ductos, distribuidoras de botanas, alimentos, diseñadoras de muebles, diseños de partes de maquinaria, empresas con gran valor agregado de las cuales se desconoce su existencia. De acuerdo con estadísticas del Directorio Empresarial del Instituto Nacional de Geografía e Informática (INEGI) más del $85.7 \%$ de las PYMES no tiene el conocimiento de los apoyos que ofrece el gobierno, y el $14.3 \%$ de las empresas tienen conocimiento de los programas de promoción y apoyo del gobierno del estado el mayor porcentaje conoce la Red de Apoyo al Emprendedor, alcanzando el $61.1 \%$, seguido por el programa Crezcamos juntos con el $42.6 \%$, así como otros programas del INADEM con el 39.4 por ciento. Esto genera una problemática ya que este tipo de empresas requieren del apoyo del sector público y de igual manera el sector publico necesita acreditar el destino de estos apoyos designados. Entones aquí nos hacemos la pregunta de investigación ¿si existen PYMES innovadoras y hay recursos en el sector público, entonces cuales son las causas de la no vinculación? Esta temática es el punto central de la presente investigación.
\end{abstract}

PYMES, INEGI, Industria manufacturera, Empresas, Sector público, Emprendedores

Citation: SALAZAR-PAVÓN, Eliazar, ESPARZA-TOVAR, Citlalli, GUILLEN-RAMÍREZ, Mirna Liliana and BECERRABUSTAMANTE, Diana Michel. Determination of the causes of the non-linking of SMEs with public entities. Journal-Public Economy. 2019. 3-5: 38-44

$\dagger$ Researcher contributing as first author 


\section{Introduction}

According to the north digital magazine (2019) and the undersecretary of economy of the state government Javier Sánchez Carlos, and according to the Business Directory of the National Institute of Geography and Informatics (INEGI), in Ciudad Juárez there are currently 38 thousand 911 medium, small and micro businesses. The undersecretary of economy of the state government Javier Sánchez Carlos gave details of the programs that support the sector at the border, he announced that the federal program that supported companies with an approximate 15.9 million pesos to join the new entrepreneurs sector.

The support that emerged since last year helping a little more than 38 thousand micro, small and medium enterprises, The Productive Social Development Support Program (FADES), provides support of up to 40 thousand pesos for investment in working capital in newly created projects in commerce, services and industry. The Program for the Promotion of Productive Activities (FAP) grants support of up to 400 thousand pesos to companies with a year of operation in commerce, services and industry, also for investment in working capital. And the Program of Support for Innovation and Technological Improvement for Micro and Small Industry (PROACTEC) grants financing of up to 500 thousand pesos for the acquisition of machinery to companies with at least one year of operation.

According to statistics from the Business Directory of the National Institute of Geography and Information Technology (INEGI) more than $85.7 \%$ of SMEs do not have the knowledge of the support offered by the government, and $14.3 \%$ of companies if they have knowledge of the programs of promotion and support of the state government the highest percentage knows the Entrepreneur Support Network, reaching $61.1 \%$, followed by the Let's Grow Together program with $42.6 \%$, as well as other INADEM programs with 39.4 percent. MSMEs account for about two thirds of global employment, but the contribution to GDP is lower, in developing countries it is $35 \%$, while in developed countries it is $50 \%$.

\section{Methodology}

In defining the problem, the reason why there is no link between the authorities and secretaries that aim to support medium and small businesses, since there are a large number of economic units in the city of Ciudad Juarez, is say why the supports, as well as programs, advice and projects that the federal government implements through the different entities such as the Ministry of Economy do not manage to have an impact and dissemination of information with these economic units, from another perspective because these SMEs They have not had the interest of approach or if they have done so, because they have not succeeded in seeking support, this is the question that arises in the investigation.

The method applied in the study is descriptive according to (Tamayo, 2011) is the type of study that only seeks to describe situations or events. This method involves several stages such as the observation, measurement and collection of data and design of instruments, for this reason the objective of the research, the field study, the application of surveys, and design of strategies for SMEs was clearly defined In the same way the explanatory method is applied, according to the edition of (Sampieri, of 2010), one of the phases is the observation, exploration, and decomposition of the phenomenon to give an explanation of the care.

For these reasons, the objective of the study is to determine the causes of the lack of rapprochement and linkage between SMEs with government institutions that offer support to these companies and the design of strategies, as well as recommendations to create an approach between them. organisms, results that will be explained in the final part of this document.

\section{SMES in Ciudad Juarez}

Different phases were designed for the implementation of this project. In the first phase the SMEs of Ciudad Juárez were located, first, a search for companies was determined in the database of the business directory of the National Institute of Geography and Information Technology (INEGI). 
In this way the segmentation of the different companies by sectors, number of employees, facilities, address, the line of business was performed, as shown in the first image of the mapping, this is how we identified footwear manufacturing companies, lathes companies, soaps , medical equipment, furniture, metal-metallic, once these companies were determined, the field investigation was carried out, which consisted of the visit of these companies in the colonies of El Granjero, Las Aztecas, zapata, centro zone, Galeana etc. In the collection of information, there was an instrument (survey) designed specifically to understand and summarize the collection of data that was required. At the time of direct visits, various situations were found, such as the acceptance of entrepreneurs and their employees, as well as the refusal and reluctance of other entrepreneurs, will be explained and applied in the corresponding topic.

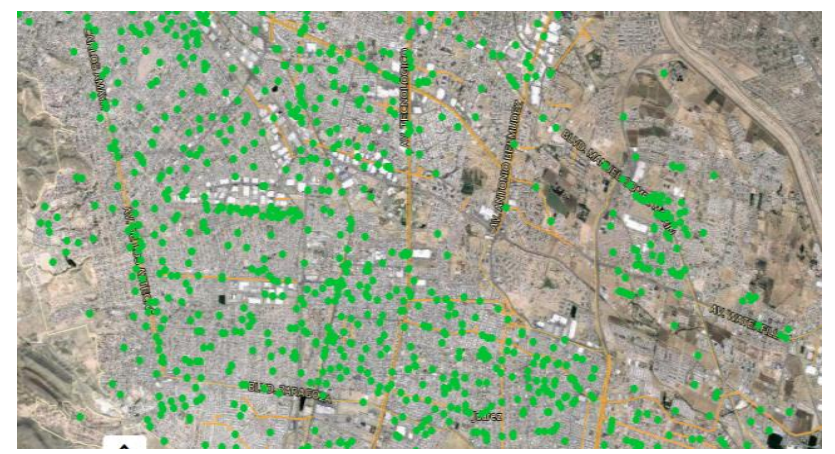

Figureure 1 mapping of companies in Ciudad Juárez: map showing the location of manufacturing companies in Ciudad Juárez INEGI.

This includes the assignment of tasks, the segmentation, the classification of the companies and the assignment of work groups. The field visits were formed by four work teams, which were composed of two members, each team was assigned One sector, the way of working of each group was through previous appointments that were made to the selected companies, visits scheduled for the application of the surveys, followed by the application of the same, these were entered into the platform of the national institute of geography and informatics (INEGI), which shows the result of each company in one day, after obtaining the results, the previous appointments are scheduled for the delivery of the instrument, after conducting a financial, market, product study, The results and current status of your company are given to the owner, and one of the ritual points was the need for capital injection.

\section{Public resources for SMES}

Once the search for small and medium-sized companies was carried out, the second phase of the investigation was carried out, which is the collection of information, of existing government support for this type of companies, at the time of conducting these investigations in the relevant institutions, it was identified that, if there are supports for these companies, and although the information, was not accessible but still in the secretary of economy the following was found:

FIDEJUAREZ (financing for the development of Ciudad Juárez), this MiPymes financing program in the commercial, service or industry sector, provides support from $\$ 100,001$ to $\$ 1,000,000$, with loans of up to $9 \%$. How do you apply for this loan? A pre-analysis is carried out which consists of registering with the SAT not to be in the credit bureau, a statement of results is delivered, the application must be previously filled through the website (www.fideapech.com .mx), through this site the application is downloaded, and the description of your business, and the applicant receives the pre-analysis in 48 hours maximum after the complete documentation is delivered on the same website, the documents and the case They appear before the committee and the technical programming committee may request additional information.

FIDEAPECH (trust for the promotion of activities in the state of Chihuahua, offers various credit options for businesses, through financing plans that are adapted according to needs, with lower market rates. The FADES program is a government support that by means of requirements discharged from the secretary of finance and the two types of support that he grants for avio or refactional credit, these two types of first qualification or avio project credit (according to quotation) and a normal interest rate of $12 \%$ and $10 \%$ and up to 18 months of taxfree credit term, the support amounts range from 5,000 to 100,000 thousand pesos, the percentage of support in FADES women is $80 \%$, rural and urban FADES $75 \%$. Maximum amount of support also of 5,000 - 100,000 thousand pesos with a $12 \%$ and $10 \%$ rate and up to 36 months of credit term and 6 months plus tax-free, including the maximum amount not included It can exceed 100,000 thousand pesos. 
The restrictions of this support cover the black line (example: purchase - sale of alcohol), to pay debts or payroll payments and purchase of goods or real estate is only support for the company.

SME FUND Program, is also basically oriented to micro businesses and small businesses, it is also an instrument that seeks to support and is particularly focused on smaller or smaller ones, whether they have very little time in the industrial field, and with more support to the entrepreneur in order to see the development of these institutions.

They are integrated by federal resources provided for in the budget of expenditures of the federation of the corresponding fiscal army and are delivered to the population through intermediate agencies with adherence to provisions of federal law and tax liability. The budget allocated to the SME FUND is at least $95.39 \%$ for the population and $4.61 \%$ for expenses associated with the efficient promotion, operation, monitoring required for execution.

It has a national coverage and its target population are entrepreneurs, micro-enterprises, small and medium-sized companies, and it asks that companies be legally established in accordance with Mexican legislation. We conclude that, if they exist at least in 2019, government support.

\section{Causes of lack of supports for smes}

As results and analysis of the present research and part of this project we detect and determine the following causes for which the SMEs do not have that approach towards public agencies. Support information has been disclosed in news, government reports, and universities have always provided information. But even so, the support does not reach the SMEs either due to corruption or lack of funds, but in the following analysis we can determine that this is not the case since the following causes were detected in Ciudad Juárez after having carried out the survey and strategic location of the SMEs.

\section{Lack of diffusion}

The lack of promotion and dissemination of federal programs for which SMEs companies can access, causes only a minimum number of companies to have these benefits, in contrast to companies that are large that have access to federal resources is larger than Micro companies, the reasons that companies give is the lack of information.

The problem is that entrepreneurs are dedicated to operating their business and not directing them, that is, they work their business by dedicating all the necessary time and leaving aside the part of resources and growth, which implies that they do not even know funding and training support programs.

It can be said that the government does not have an important space to expand information on the economic support programs it offers to companies, and thus allow more competitive access to them. The information is disseminated exclusively in government offices and in public events for this reason this cause has its reason for not getting to where the entrepreneur is.

\section{Bureaucratic process}

On the other hand, the companies that have the knowledge of the state support, have to do a process to be able to access the benefits of the requested program, a process that is delayed, so many of the companies lose motivation when performing the process, in view of the fact that you have to review the requested documents and validate what is related to the company, this causes the entrepreneur or owner to return on several occasions to know the process situation and it is at this point where it bothers him and delays.

\section{Lack of motivation}

Another cause found in companies is the lack of motivation of the same, for several reasons:

1. You don't have the knowledge of the government's programs,

2. the process to process support is long and late

3. Companies are not registered with the Ministry of Finance and Public Credit 
4. they are afraid that the programs have an interest rate that is too high for them

With the above, you can see that companies do not have the right training to clarify doubts and give them advice on how they can grow the company. This point is very simple since it is caused by the thought of social fatigue.

\section{Lack of SMEs planning}

Planning can be described as a systematic process in which the organization establishes a path (methodology) to achieve its objectives.

The problem that small and medium-sized companies have had to overcome is globalization, this situation forced many of these companies to close due to the large number of business transactions that arrived in our country, With the passage of time many of the small and medium enterprises have been affected by these changes that have occurred in our environment. Many of these companies do not have professional advice to adapt to the market.

\section{Lack of entrepreneurship culture}

Entrepreneurship in Mexico is progressing slowly. The number of people who start a business is increasing, but their efforts are diminished by the lack of financing, fiscal policy, excessive procedures and lack of planning. Some of the reasons why companies do not have the culture of entrepreneurship:

\section{- $\quad$ Lack of business vision \\ - $\quad$ There are no suitable equipment \\ - $\quad$ Renewal of ideas. \\ - $\quad$ Little financing \\ - $\quad$ Missing network of mentors.}

\section{Results and strategies}

Once the surveys and the field study were carried out, as well as the visits to small and medium enterprises located in Ciudad Juárez, the following was determined:

\begin{tabular}{|l|c|}
$\begin{array}{l}\text { Causes of the non-linking of the smes with the public } \\
\text { sector }\end{array}$ & $\begin{array}{c}\text { N } \\
\mathbf{0}\end{array}$ \\
\hline Lack of entrepreneurship culture & 5 \\
\hline They had no information on government programs & 40 \\
\hline If they had information but they are not interested & 15 \\
\hline Bureaucratic process & 30 \\
\hline It has no motivation & 10 \\
\hline Companies surveyed & $\mathbf{8 0}$ \\
\hline
\end{tabular}

Table 1 shows the percentage of SMES companies that were surveyed (unpublished thesis) 2019

As we can see from the most common causes that were found, it is the lack of information and indeed as different studies support it, that government program does not have enough diffusion or projection and this is due to the little maneuver and budget of the companies. In the background we have some who already had the information even though they started the process of requesting some support, this process has been bureaucratic, tedious, delayed and full of requirements that the SMEs have not yet been able to meet as they are, ( RFC, proof of credit bureau, faithful, among others). These are the number of SMEs that have faced this situation.

\section{Strategies for decreasing the problem}

Ahora bien, una vez que se ha conocido esta situación, el siguiente paso es determinar las estrategias para el apoyo a estas empresas y como se explicó en el capítulo anterior de las causas de la falta de apoyo económico en las SMEs, se determinó que fueron variados los motivos que ocasionan que los apoyos económicos no lleguen a su destino y por tan motivo y como resultado de la presente investigación se tomaron las siguientes estrategias para beneficiar las SMEs.

\section{Linking with public agencies:}

As previously discussed, one of the main causes is the lack of information, and for this problem the following measure was taken; link directly to the SMEs that is, send the information to the SMEs of the economic funds and supports offered by the state and federal government, as part of this project was given the task of inquiring about the resources and supports that exist in dependencies like. 
PROMEXICO, INADEM，SIDE，SE, among others, information that was collected through packages and brochures and by email, this information was also delivered to the SMEs personally and by email as well as the delivery of brochures, plans, credits, requirements, links, telephones, among others. The reaction of the entrepreneurs was very satisfactory, and of surprise since they commented that the funds and credits were very good, and that they could obviously help them to grow as a company or to have other projects and expressed their total approval and probable process for the future. they were mentioned that these supports varied every year but still they never informed about the funds.

\section{Informative talks and advice:}

For this strategy, an audiovisual space was enabled at the Technological University Paso del Norte to receive these companies which were informed by email that was sent to each of the companies with an attachment where the time was indicated and the date of the program as informative talks and free advice,

This advisory plan was given so that companies could give a little more feedback on the subject. As a second phase they were shared with the consultant, clarifying doubts that the applicants had, such as filling out the documents, formats, and other information. Likewise, companies were informed a little more of the benefits that these dependencies grant to SMEs, clarifying the doubts they might have when listening more through an expert, which is something simple than it seemed.

As the third and final phase of the process of informative talks and advice, the companies that were left with doubts were channeled one by one by the advisor, they were clarifying doubts and questions they had, they were also distributed brochures and other information, they were asked approaching the public agencies of government support that the secretary of economy has online since if they had not obtained enough information from the platforms they could find everything that had been reported in the talk. Similarly, they are advised on the weaknesses of your company, finance, advertising and market.

\section{Development of diagnoses:}

In this part of the project, the work team was given the task of preparing surveys and applying them to SMEs, which contained basic questions for companies and were of great value to know the capabilities they had and some tools that we might consider necessary to the development of this diagnosis different means of how to know more about some deficiencies or strengths of companies, example: how many employees do you have and questions such as strategists and market share and business development.

In the surveys, the entire structure of the company is mentioned in a certain way in the plan to also make known the type of product they handle and how the different strategies of who can be the possible comparators of the elaborated product are created. (finance, mission, vision, market research, expansion, No of employees, facilities, people, machinery among other aspects).

The following are the following tables and graphs that represent the percentages of the 80 companies which were surveyed and analyzed.

\begin{tabular}{|l|l|}
\hline \multicolumn{1}{|c|}{ Smes Supported } & No \\
\hline Linking with public agencies & 20 \\
\hline Informative talks and advice & 30 \\
\hline Diagnostic Development & 30 \\
\hline Linked businesses & 80 \\
\hline
\end{tabular}

Table 2 shows the percentage of SMEs in which the project strategies were implemented (unpublished thesis) 2019

The little information available and the asymmetry between state government agents, the resistance of state governments to provide information, despite the fact that there is a transparency law and that the study refers exclusively to Mexico. (Góngora Biachi \& Madrid Guijarro, April, 2010). They conclude in their report the support for innovation of SMEs in Mexico, and point out that the main limitations of the study are: That the study is focused on a single type of sector support, despite the convergence of programs to give it more strength to the Fund and that there are additional supports such as export or those related to the field, with conditions that could make them accessible to the SMEs. 
And as a final part it was determined that the main cause for which entrepreneurs do not resort to information on aid or support is the process and bureaucracy, adding to this the little information that exists of these supports and in the information channels of the dependencies of government where it was detected that they are not effective, but as a non-measurable factor and that was detected in the investigation but where the main source of the non-linking of SMEs with the public sector is the distrust that in these years has generated by the federal and state government as municipal, by not respecting the processes and not designing an accessible and effective instrument for SMEs, for this reason institutions such as universities, colleges, associations and all those bodies that can support this link are a important part for the SMEs and their growth as of our country to detonate the economic growth of the town.

\section{References}

INEGI. (2014). Micro, pequeña, mediana y gran empresa Estratificación de los establecimientos. http://internet.contenidos.inegi.org.mx/contenid os/productos/prod_serv/contenidos/espanol/bvi negi/productos/nueva_estruc/702825077952.pd $\mathrm{f}$

Jacques, F.L; Cisneros, L.F.; Mejía-Morelos, J. H. (2011). Administración de SMES. Emprender, dirigir y desarrollar empresas. Primera edición. Ed. Pearson educación, México.

Mendoza, L. (2014). Diseño de una metodología para la consultoría de empresas. (Tesis inédita de maestría). Instituto politécnico nacional. México, D.F.

Sampieri, R. (2006). Metodología de la investigación. México: Mc Graw Hill. 